\title{
PEMBELAJARAN STEM (SCIENCE TECHNOLOGY ENGINEERING AND MATHEMATICS) DALAM MENINGKATKAN KREATIVITAS CALON GURU PENDIDIKAN MATEMATIKA DI ERA 4.0
}

\author{
Mia Nurkanti ${ }^{1}$, Jusep Saputra ${ }^{2}$ \\ ${ }^{1,2}$ Universitas Pasundan \\ 1mia.nurkanti@unpas.ac.id \\ 2jusepsaputrapmat@unpas.ac.id
}

\begin{abstract}
ABSTRAK
Pendidikan 4.0 merupakan pendidikan yang bercirikan pemanfaatan teknologi digital dalam proses pembelajaran atau dikenal dengan sistem siber (cyber system). Tujuan penelitian ini yaitu 1) menganalisis pembelajaran STEM (science, technology, engineering and mathematics) dalam meningkatkan kemampuan keterampilan kreatif mahasiswa pendidikan matematika, 2) mengetahui seberapa besar pembelajaran STEM (science, technology, engineering and mathematics) mampu meningkatkan kemampuan keterampilan kreatif mahasiswa pendidikan matematika. Penelitian ini didesain sebagai penelitian pra eksperimen. Desain penelitian one case study. Kelompoknya satu dalam arti, subjek yang mengambil atau mengontrak 1 mata Kuliah. Dalam hal ini subjeknya berasal dari Prodi Pendidikan Matematika yang mengontrak Mata Kuliah Aljabar Matriks. Kelas A terdiri dari 35 orang dan Kelas B terdiri dari 26 orang. Kaitannya dengan teknologi dalam pembelajaran STEM, pembelajaran dilakukan dengan menggunakan ICT yaitu program maple. Analisis data yang digunakan adalah analisis data pretest, posttest, dan N-Gain. Masing-masing di analisis statistika deskriptinya, kemudian di analisis statistika inferensialnya untuk melihat signifikansi kategori peningkatan masing-masing kelas. Pembelajaran STEM secara deskriptif mampu peningkatan kemampuan kreatif dengan kategori sedang di Kelas A dan kategori tinggi di Kelas B, meskipun tidak meningkat secara signifikan. Tidak terdapat perbedaan peningkatan yang signifikan kemampuan kreatif antara kelas A dan B, karena mempunyai nilai rata-rata peningkatan yang hampir sama.
\end{abstract}

Kata Kunci: STEM, Kreativitas, Calon Guru, Era 4.0.

\begin{abstract}
Education 4.0 is an education characterized by the use of digital technology in the learning process or known as the cyber system. The purpose of this study is 1) analysing STEM learning (science, technology, engineering and mathematics) in improving the ability of creative skills of mathematics education students, 2) knowing how much STEM learning (science, technology, engineering and mathematics) is able to increase the ability of creative skills of educational students' mathematics. This research was designed as a pre-experimental research. One case study design. The group is one in a sense, a subject who takes or contracts 1 course. In this case the subject comes from the Mathematics Education Study Program who contracted the Matrix Algebra Course. Class A consists of 35 people and Class B consists of 26 people. In relation to technology in STEM learning, learning is carried out using ICT which is the maple program. Analysis of the data used is the analysis of pretest, posttest, and N-gain data. Each of the statistical analysis descriptors, then inferential statistical analysis to see the significance of the category improvement of each class. STEM learning in a descriptive manner is able to increase creative abilities with a moderate category in Class A and a high category in Class B, although it does not increase significantly. There is no significant difference in the increase in creative ability between classes $\mathrm{A}$ and $\mathrm{B}$, because it has an average value of almost the same increase.
\end{abstract}


Keywords: STEM, Creativity, Prospective Teachers, 4.0 Era.

\section{PENDAHULUAN}

Menghadapi tantangan besar dunia pendidikan dituntut untuk berubah juga mengikuti perkembangan zaman. Termasuk pendidikan pada jenjang pendidikan dasar dan menengah. Era pendidikan yang dipengaruhi oleh revolusi industri 4.0 disebut Pendidikan 4.0. Pendidikan 4.0 merupakan pendidikan yang bercirikan pemanfaatan teknologi digital dalam proses pembelajaran atau dikenal dengan sistem siber (cyber system). Sistem ini mampu membuat proses pembelajaran dapat berlangsung secara kontinu tanpa batas ruang dan batas waktu (Darmawan: 2018).

Pembelajaran dengan menggunakan ICT mempunyai pengaruh positif. Menurut Yaniawati, Kartasasmita \& Saputra (2019, hlm. 2), “Utilization of e-learning in mathematics has positive influences. Other than as an effort in solving technical problem as learning media, this can also become an effort to address substantial learning problem as learning material".

Nurhayati, Nunung \& Wijayanti (2017) dalam penelitiannya mengenai kemampuan mahasiswa keterampilan kreatif pada konsep optik menunjukkan (1) Persentase mahasiswa yang memiliki kemampuan keterampilan kreatif kategori sangat baik adalah sebesar 15,79\%, kategori baik sebesar 31,58\%, kategori cukup sebesar 42,11\%, dan kategori kurang sebesar 10,53\%; (2) Persentase kemampuan mahasiswa dalam menjawab soal tingkatan menganalisis sebesar 68,42\%, kemampuan mahasiswa dalam menjawab soal tingkatan mengevaluasi sebesar $57,89 \%$ dan sebesar 53,51\% untuk kemampuan mahasiswa dalam menjawab soal tingkatan mencipta.

Tujuan penelitian ini yaitu 1) menganalisis pembelajaran STEM (science, technology, engineering and mathematics) dalam meningkatkan kemampuan keterampilan kreatif mahasiswa pendidikan matematika, 2) mengetahui seberapa besar pembelajaran STEM mampu meningkatkan kemampuan keterampilan kreatif mahasiswa pendidikan matematika.

Penelitian ini dirasa penting karena 1). Penelitian ini akan mengemas pembelajaran STEM yang mampu menstimulasi keterampilan kreatif mahasiswa sehingga muncul kemampuan yang didasari dengan kekuatan berpikir mulai dari berpikir kritis, analitis, kreatif dan inovatif, 2). Pembelajaran STEM selama ini belum diaplikasikan di FKIP Unpas khususnya sehingga peneliti memandang sangat perlu guna meningkatkan keterampilan kreatif mahasiswa calon guru. Dengan model pembelajaran yang baik diharapkan muncul generasi penerus bangsa 
yang berkualitas dan mampu berkontribusi untuk masyarakat, bangsa dan bernegara. Menurut Darta \& Saputra (2018, hlm. 2), “The Director-General of Teachers and Education Personnel $(G T K)$ reported that based on the results of Teacher Competency Test (UKG) administered at the end of 2015, the average scores were 53.02. The competencies tested are professional competence and pedagogic competency. Based on the data, it is still necessary to improve the quality of teachers in Indonesia”.

Penelitian yang dilakukan oleh Pertiwi, Abdurrahman, Rosidin (2017) berjudul Efektivitas LKS STEM Untuk Melatih Keterampilan Berpikir Kreatif Siswa menunjukkan bahwa LKS telah efektif digunakan dalam proses pembelajaran, dilihat dari hasil rerata nilai posttest $(81,4)>$ nilai rerata pretest $(42,3)$ dan nilai $n$-Gain kelas eksperimen $(0,71)>$ kelas kontrol $(0,45)$. Berdasarkan hasil uji hipotesis dengan nilai Sig sebesar 0,000<0,05, diketahui bahwa terdapat perbedaan antara rata-rata nilai pada kelas eksperimen dengan nilai pada kelas kontrol. LKS yang telah dikembangkan efektif melatih keterampilan berpikir kreatif siswa dilihat dari peningkatan keterampilan berpikir siswa pada setiap indikatornya. Keterampilan berpikir kreatif siswa mengalami peningkatan untuk setiap indikator. Berdasarkan penelitian yang telah dilakukan, dapat disimpulkan bahwa LKS dengan pendekatan STEM telah efektif dalam melatih keterampilan berpikir kreatif siswa. jurnal pembelajaran fisika vol 5, NO 2 (2017).

Penelitian yang dilakukan oleh Thibaut, Knipprath, Dehaene, \& Depaepe (2018), Berjudul The Influence of Teachers' Attitudes and School Context on Instructional Practices in Integrated STEM Education menunjukkan bahwa praktek pembelajaran STEM untuk menguji pengaruh sikap dan guru yang terintegrasi lima karakteristik khusus (integrasi, pembelajaran yang berpusat pada masalah, berbasis penyelidikan, berbasis desain, dan kooperatif) menunjukkan guru mendapatkan wawasan mendalam, sikap guru positif terkait dengan praktek pembelajaran.

Ketika STEM dipandang dari sudut pandang pendidikan, maka hal itu bukanlah hanya sebuah slogan atau akronim tapi mempunyai suatu tujuan dan pencapaian dalam pendidikan: tujuan pendidikan STEM (STEM education) bagi semua siswa adalah menerapkan dan mempraktekkan konten dasar dari STEM pada situasi yang mereka hadapi dalam kehidupan, menjadi "melek" STEM (STEM literacy) (Bybee, 2013). 
Definisi STEM menurut National Research Council (NRC) (2014, hlm. 1) Sains adalah tubuh pengetahuan yang telah terakumulasi dari waktu ke waktu dari sebuah pemeriksaan ilmiah yang menghasilkan pengetahuan baru. Ilmu pengetahuan dan sains berperan menginformasikan pross rancangan teknik, 2) Teknologi adalah keseluruhan sistem dari orang dan organisasi, pengetahuan, proses dan perangkat-perangkat yang kemudian menciptakan benda dan mengoperasionalkannya. Manusia telah menciptakan teknologi untuk memuaskan keinginan dan kebutuhannya. Banyak dari teknologi moderen adalah produk dari sains dan teknik, 3) Teknik merupakan tubuh pengetahuan tentang desain dan penciptaan benda buatan manusia dan sebuah proses untuk memecahkan masalah. Teknik memanfaatkan konsep dalam sains, matematika dan alat-alat teknologi, 4) Matematika adalah studi tentang pola dan hubungan antara jumlah, angka, dan ruang. Matematika digunakan dalam sains, teknik dan teknologi. Dalam hal ini teknologi yang digunakan adalah Program Maple. Menurut Saputra (2017a, hlm. 65), "The Maple program helps someone searching mathematical solutions for researchers, mathematicians, faculty and learners easily and quickly without having to get stuck in the difficulty or complexity of mathematical computing. or even the difficulty and complexity of the computer".

Walaupun ada pengakuan ilmiah terhadap pentingnya kreativitas, namun hingga kini hanya sedikit sekali penelitian yang telah dilakukan. Hal itu disebabkan adanya kesulitan metodologi dan karena adanya keyakinan bahwa kreativitas adalah suatu faktor bawaan individual sehingga hanya sedikit yang dapat dilakukan untuk mengendalikannya. Beberapa pengertian kreativitas menurut para ahli diantaranya adalah sebagai berikut.

Munandar (1995, hlm. 25) kreativitas adalah suatu kemampuan umum untuk menciptakan suatu yang baru, sebagai kemampuan untuk memberikan gagasan-gagasan baru yang dapat diterapkan dalam pemecahan masalah, atau sebagai kemampuan untuk melihat hubungan-hubungan baru antara unsur-unsur yang sudah ada sebelumnya.

Imam Musbikin (2006, hlm. 6) kreativitas adalah kemampuan memulai ide, melihat hubungan yang baru, atau tak diduga sebelumnya, kemampuan memformulasikan konsep yang tak sekedar menghafal, menciptakan jawaban baru untuk soal-soal yang ada, dan mendapatkan pertanyaan baru yang perlu di jawab.

Mangunhardjana (1986, hlm. 11) adalah kegiatan yang mendatangkan hasil yang sifatnya berguna (useful), lebih enak, lebih praktis, mempermudah, memperlancar, mendorong, 
mengembangkan, mendidik, memecahkan masalah, mengurangi hambatan, mengatasi kesulitan, mendatangkan hasil lebih baik atau banyak.

Sternberg (1988), kreativitas merupakan titik pertemuan yang khas antara tiga atribut psikologis, yaitu inteligensi, gay a kognitif, dan kepribadian/motivasi. Begitupula Baron (1969) yang menyatakan kreativitas adalah kemampuan untuk menghasilkan atau menciptakan sesuatu yang baru.

Supriyadi (dalam Rachmawati \& Kurniati, 2005, hlm. 15) mengutarakan bahwa kreativitas adalah kemampuan seseorang untuk melahirkan sesuatu yang baru, baik berupa gagasan maupun karya nyata yang relatif berbeda dengan apa yang telah ada. Selanjutnya ia menambahkan bahwa kreativitas merupakan kemampuan keterampilan kreatif yang mengimplikasikan terjadinya eskalasi dalam kemampuan berpikir, ditandai oleh suksesi, diskontinuitas, diferensiasi, dan integrasi antara setiap tahap perkembangan.

Torrance (1988), kreativitas adalah proses merasakan dan mengamati adanya masalah, membuat dugaan tentang kekurangan (masalah) ini, menilai dan menguji dugaan atau hipotesis, kemudian mengubah dan mengujinya lagi, dan akhirnya menyampaikan hasil-hasilnya.

'Dari berbagai pengertian yang dikemukakan oleh para ahli untuk menjelaskan makna dari kreativitas penulis mengambil kesimpulan bahwa kreativitas adalah kemampuan menciptakan sesuatu yang baru, proses konstruksi ide yang dapat diterapkan dalam menyelesaikan masalah, serta suatu kegiatan yang bermanfaat.

Adapun definisi kreativitas tergantung pada segi penekanannya, kreativitas dapat didefinisikan ke dalam empat jenis dimensi sebagai Four P's Creativity, yaitu dimensi Person, Proses, Press dan Product sebagai berikut: (1) Definisi kreativitas dalam dimensi Person. Definisi pada dimensi person adalah upaya mendefinisikan kreativitas yang berfokus pada individu atau person dari individu yang dapat disebut kreatif. "Creativity refers to the abilities that are characteristics of creative people” (Guilford dalam Reni, A. \& Hawadi, 2001). "Creative action is an imposing of one's own whole personality on the environment in a unique and characteristic way" (Hulbeck dalam Munandar, 2004). Guilford menerangkan bahwa kreativitas merupakan kemampuan atau kecakapan yang ada dalam diri seseorang, hal ini erat kaitannya dengan bakat. Sedangkan Hulbeck menerangkan bahwa tindakan kreatif muncul dari keunikan keseluruhan kepribadian dalam interaksi dengan lingkungannya. Definisi kreativitas dari dua pakar diatas lebih berfokus pada segi pribadi. (2) Kreativitas dalam dimensi Process. 
Definisi pada dimensi proses upaya mendefinisikan kreativitas yang berfokus pada proses berpikir sehingga memunculkan ide-ide unik atau kreatif. "Creativity is a process that manifest in self in fluency, in flexibility as well in originality of thinking" (Munandar 2004). Munandar menerangkan bahwa kreativitas adalah sebuah proses atau kemampuan yang mencerminkan kelancaran, keluwesan (fleksibilitas), dan orisinalitas dalam berpikir, serta kemampuan untuk mengelaborasi (mengembangkan, memperkaya, memerinci), suatu gagasan. Pada definisi ini lebih menekankan pada aspek proses perubahan (inovasi dan variasi). Dari pendapat diatas kreativitas sebagai sebuah proses yang terjadi di dalam otak manusia dalam menemukan dan mengembangkan sebuah gagasan baru yang lebih inovatif dan variatif (divergensi berpikir). (3) Definisi Kreativitas dalam dimensi Press. Definisi dan pendekatan kreativitas yang menekankan faktor press atau dorongan, baik dorongan internal diri sendiri berupa keinginan dan hasrat untuk mencipta atau bersibuk diri secara kreatif, maupun dorongan eksternal dari lingkungan sosial dan psikologis. Definisi Simpson (1982) dalam Munandar (2004), merujuk pada aspek dorongan internal dengan rumusannya sebagai berikut: "The initiative that one manifests by his power to break away from the usual sequence of thought". Mengenai "press" dari lingkungan, ada lingkungan yang menghargai imajinasi dan fantasi, dan menekankan kreativitas serta inovasi. Kreativitas juga kurang berkembang dalam kebudayaan yang terlalu menekankan tradisi, dan kurang terbukanya terhadap perubahan atau perkembangan baru. (4) Definisi Kreativitas dalam dimensi Product. Definisi pada dimensi produk merupakan upaya mendefinisikan kreativitas yang berfokus pada produk atau apa yang dihasilkan oleh individu baik sesuatu yang baru/original atau sebuah elaborasi/penggabungan yang inovatif.

"Creativity is the ability to bring something new into existence" (Baron dalam Reni, A. \& Hawadi). Definisi yang berfokus pada produk kreatif menekankan pada orisinalitas, seperti yang dikemukakan oleh Baron (1969) yang menyatakan bahwa kreatifitas adalah kemampuan untuk menghasilkan/menciptakan sesuatu yang baru. Begitu pula menurut Haefele (dalam Munandar, 1999); yang menyatakan kreativitas adalah kemampuan untuk membuat kombinasikombinasi baru yang mempunyai makna sosial. Dari dua definisi ini maka kreatifitas tidak hanya membuat sesuatu yang baru tetapi mungkin saja kombinasi dari sesuatu yang sudah ada sebelumnya.

Dari berbagai pengertian yang dikemukakan oleh para ahli untuk menjelaskan makna dari kreativitas yang dikaji dari empat dimensi yang memberikan definisi saling melengkapi. 
Untuk itu kita dapat membuat berbagai kesimpulan mengenai definisi tentang kreativitas dengan acuan beberapa pendapat yang dikemukakan oleh para ahli. Definisi kreativitas yang dikemukakan diatas peneliti menyimpulkan bahwa: "Kreativitas adalah proses konstruksi ide yang orisinal (asli), bermanfaat, variatif (bernilai seni) dan inovatif (berbeda/lebih baik)".

Strategi 4P yaitu Pribadi, Pendorong, Proses, dan Produk yang menurut para ahli dapat membantu mengembangkan kreatifitas anak jika diterapkan secara benar. Pada dasarnya setiap anak memiliki kreativitas, hanya saja tidak semua anak bisa mengembangkan kreatifitasnya dengan benar. Untuk itu diperlukan peran orang tua dalam mengembangkan kreatifitas tersebut. Melalui strategi $4 \mathrm{P}$ ini diharapkan dapat membantu orang tua dalam mengembangkan kreativitas anaknya.

\section{Pribadi}

Hal pertama yang harus orang tua ketahui dalam upaya mengembangkan kreatifitas anak adalah dengan memahami pribadi mereka, diantaranya dengan: 1) Memahami bahwa setiap anak memiliki pribadi berbeda, baik dari bakat, minat, maupun keinginan, 2) Menghargai keunikan kreativitas yang dimiliki anak, dan bukan mengharapkan hal-hal yang sama antara satu anak dengan anak lainnya, karena setiap anak adalah pribadi yang "unik", dan kreatifitas juga merupakan sesuatu yang unik, 3) Jangan membanding-bandingkan anak karena tiap anak memiliki minat, bakat, kelebihan serta ketebatasannya masing-masing. Pahamilah kekurangan anak dan kembangkanlah bakat dan kelebihan yang dimilikinya.

\section{Pendorong}

Dorongan dan motivasi bagi anda sangat berguna bagi anak dalam mengembangkan motivasi intrinsik mereka, dengan begitu mereka akan sendirinya berkreasi tanpa merasa dipaksa dan dituntut ini itu, kita dapat melakukan, a) Berilah fasilitas dan sarana bagi mereka untuk berkreasi, misalnya melalui mainan-mainan yang bisa merangsang daya kreativitas anak misalnya balok-balok susun, lego, mainan alat dapur dan sebagainya. Hindari memberikan mainan yang tinggal pencet tombol atau mainan langsung jadi, b) Ciptakan lingkungan keluarga yang mendukung kreatifitas anak dengan memberikan suasana aman dan nyaman, c) Hindari membatasi ruang gerak anak di dalam rumah karena takut ada barang-barang yang pecah atau rusak, karena cara ini justru bisa memasung kreativitas mereka, alangkah lebih baik jika anda mau mengalah dengan menyimpan dahulu barang-barang yang mudah pecah ke tempat yang 
aman, atau anda bisa menyediakan tempat khusus bermain anak, dimana anak bebas berkreasi,

d) Disiplin tetap diperlukan agar ide-ide kreatif mereka bisa terwujud.

\section{Proses}

Proses berkreasi merupakan bagian paling penting dalam pengembangan kreativitas dimana anak anda akan merasa mampu dan senang bersibuk diri secara kreatif dengan aktifitas yang dilakukannya, baik melukis, menyusun balok, merangkai bunga dan sebagainya, beberapa hal yang dapat dilakukan, a) Hargailah kreasinya tanpa perlu berlebihan, karena secara intuitif anak akan tahu mana pujian yang tulus dan yang mana yang hanya akan basa-basi, b) Hindari memberi komentar negatif saat anak berkreasi, apalagi disertai dengan perintah ini itu terhadap karya yang sedang dibuatnya, karena hal ini justru dapat menyurutkan semangatnya berkreasi, c) Peliharalah harga diri anak dengan mengungkapkan terlebih dahulu komentar anda secara positif, misalnya "bunda senang adik bisa membuat menara seperti itu, lain kali adik buat yang lebih tinggi dan tidak mudah ambruk ya." Dengan demikian anak akan merasa dirinya mampu dan dihargai lingkungannya

\section{Produk}

Pada tahap ini anak sudah bisa menghasilkan produk kreatif mereka, yang bisa dilakukan, a). Hargailah hasil kreatifitas mereka meski hasilnya agak kurang memuaskan, b) Pajanglah karya anak anda di kamar mereka atau tempat-tempat lain yang memungkinkan. Dengan demikian, anak akan merasa bangga karena karyanya dihargai.

\section{METODE PENELITIAN}

Penelitian ini didesain sebagai penelitian pra eksperimen. Desain penelitian one case study. Kelompoknya satu dalam arti, subjek yang mengambil atau mengontrak 1 mata Kuliah. Dalam hal ini subjeknya berasal dari Prodi Pendidikan Matematika yang mengontrak Mata Kuliah Aljabar Matriks. Kelas A terdiri dari 35 orang dan Kelas B terdiri dari 26 orang.

Kaitannya dengan teknologi dalam pembelajaran STEM, pembelajaran dilakukan dengan menggunakan ICT yaitu program maple. Menurut Saputra (2015, hlm. 599), "Program aplikasi maple ini mampu melakukan komputasi matematis secara mudah dan cepat tanpa mensyaratkan menguasai suatu bahasa pemrograman komputer tertentu, sehingga bagi orang yang tidak menguasai bahasa pemrograman komputer sekalipun akan mampu menggunakan program maple ini”. Hal itu sesuai pula dengan penelitian selanjutnya yang dilakukan oleh 
Saputra (2017b, hlm. 118), bahwa "Pemanfaatan e-learning (maple), selain sebagai upaya mengatasi permasalahan teknis pembelajaran (media pembelajaran), juga sebagai upaya menjawab masalah substansial pembelajaran (sumber ajar)". Akibatnya program maple cocok dilakukan dalam penelitian ini. Pembelajaran STEM sebagian dilakukan di luar kelas, yaitu di lararium, karena menurut Suyadi (Maulana dan Saputra, 2018, hlm. 31), "Belajar dengan metode Outdoor Learning memiliki kekuatan antara lain, 1) Dengan pembelajaran yang variatif siswa akan segar berpikir karena suasana yang berganti, 2) Inkuiri lebih berproduksi, 3) Akselerasi lebih terpadu dan spontan, 4) Kemampuan eksplorasi lebih runtut, dan 4) Menumbuhkan penguatan konsep".

Aspek yang diteliti dalam penelitian ini adalah kemampuan berpikir kreatif mahasiswa, maka teknik pengumpulan data pada penelitian ini adalah dengan pemberian soal tes berdasarkan indikator berpikir kreatif. Instrumen penilaian yang dapat mengukur keterampilan berpikir kreatif peserta didik adalah instrumen soal uraian (esai) yang menuntut jawaban kreatif dan dilengkapi rubrik penilaian yang sesuai dengan komponen berpikir kreatif menurut ahli (Marwiyah. A. \& Umar, K. M.).

Analisis data yang digunakan adalah analisis data pretest, posttest, dan N-Gain. Masingmasing di analisis statistika deskriptinya, kemudian di analisis statistika inferensialnya untuk melihat signifikansi kategori peningkatan masing-masing kelas.

\section{HASIL DAN PEMBAHASAN}

\section{Data pretest dan posttest}

Pada penelitian ini, peneliti menggunakan sampel FKIP dari Pendidikan Matematika yang mengontrak Mata Kuliah Aljabar Matriks. Berikut jumlah data sampel yang digunakan.

Tabel 1. Jumlah Data Sampel Penelitian

Case Processing Summary

\begin{tabular}{lllllccr}
\hline & \multirow{2}{*}{ Kelas } & \multicolumn{6}{c}{ Cases } \\
\cline { 3 - 8 } & & \multicolumn{2}{c}{ Valid } & \multicolumn{2}{c}{ Missing } & \multicolumn{2}{c}{ Total } \\
\cline { 2 - 8 } Jumlah & Kelas A & 35 & Percent & N & Percent & N & Percent \\
\hline sampel & Kelas B & 26 & $100.0 \%$ & 0 & $0.0 \%$ & 35 & $100.0 \%$ \\
\hline
\end{tabular}

Berdasarkan Tabel 1, jumlah mahasiswa yang menjadi subjek penelitian sebanyak 61 orang. Subjek terdiri dari 35 orang dari Kelas A dan 26 orang dari Kelas B. 
Statistika Deskripsi

Tabel 2. Statistika Deskriptif Pretes

Descriptives

\begin{tabular}{|c|c|c|c|c|c|}
\hline & Kelas & & & Statistic & Std. Error \\
\hline & & Mean & & 1.6029 & .07542 \\
\hline & & $95 \%$ Confidence Interval & Lower Bound & 1.4496 & \\
\hline & & for Mean & Upper Bound & 1.7561 & \\
\hline & & $5 \%$ Trimmed Mean & & 1.6071 & \\
\hline & & Median & & 1.6000 & \\
\hline & & Variance & & .199 & \\
\hline & Kelas A & Std. Deviation & & .44622 & \\
\hline & & Minimum & & .50 & \\
\hline & & Maximum & & 2.50 & \\
\hline & & Range & & 2.00 & \\
\hline & & Interquartile Range & & .60 & \\
\hline & & Skewness & & -.330 & .398 \\
\hline Pretect & & Kurtosis & & -.169 & .778 \\
\hline Pretest & & Mean & & 1.8038 & .07179 \\
\hline & & 95\% Confidence Interval & Lower Bound & 1.6560 & \\
\hline & & for Mean & Upper Bound & 1.9517 & \\
\hline & & $5 \%$ Trimmed Mean & & 1.8085 & \\
\hline & & Median & & 2.0000 & \\
\hline & & Variance & & .134 & \\
\hline & Kelas B & Std. Deviation & & .36604 & \\
\hline & & Minimum & & 1.00 & \\
\hline & & Maximum & & 2.50 & \\
\hline & & Range & & 1.50 & \\
\hline & & Interquartile Range & & .50 & \\
\hline & & Skewness & & -.373 & .456 \\
\hline & & Kurtosis & & -.231 & .887 \\
\hline
\end{tabular}

Data pretest dikonversi ke dalam bentuk nilai dengan skala Indeks Prestasi (IP) yaitu 0,00 sampai 4,00. Nilai minimum kelas A dan B adalah 0,50 dan 1,00. Nilai maksimum kedua kelas sama yaitu 2.50. Nilai rata-rata kedua kelas yaitu 1.6 dan 1.8. Hal ini menunjukkan bahwa ratarata kemampuan Kelas B lebih baik daripada Kelas A, tetapi perbedaannya tidak signifikan. Jika dilihat dari standar deviasinya, Kelas A dan B yaitu 0.45 dan 0,37. Standar deviasi Kelas A lebih besar dari Kelas B artinya nilai-nilai individu di kelas A lebih jauh dari nilai rata-ratanya dibandingkan nilai-nilai individu di Kelas B dari rata-ratanya.

Sedangkan data posttest ditampilkan pada tabel 3. Data tersebut dikonversi ke dalam bentuk nilai dengan skala Indeks Prestasi (IP) yaitu 0,00 sampai 4,00. Nilai minimum kelas A dan $B$ adalah 1,50 dan 2,20. Nilai maksimum kedua kelas sama yaitu 4,0. Nilai rata-rata kedua kelas yaitu 3,2 dan 3,5. 
Tabel 3. Statistika Deskriptif Postest

\begin{tabular}{|c|c|c|c|c|c|}
\hline \multicolumn{6}{|c|}{ Descriptives } \\
\hline & Kelas & & & Statistic & Std. Error \\
\hline \multirow{26}{*}{ Postest } & \multirow{13}{*}{ Kelas A } & Mean & & 3.2000 & .09482 \\
\hline & & 95\% Confidence Interval & Lower Bound & 3.0073 & \\
\hline & & for Mean & Upper Bound & 3.3927 & \\
\hline & & $5 \%$ Trimmed Mean & & 3.2381 & \\
\hline & & Median & & 3.2000 & \\
\hline & & Variance & & .315 & \\
\hline & & Std. Deviation & & .56099 & \\
\hline & & Minimum & & 1.50 & \\
\hline & & Maximum & & 4.00 & \\
\hline & & Range & & 2.50 & \\
\hline & & Interquartile Range & & .80 & \\
\hline & & Skewness & & -1.052 & .398 \\
\hline & & Kurtosis & & 1.431 & .778 \\
\hline & \multirow{13}{*}{ Kelas B } & Mean & & 3.4885 & .10020 \\
\hline & & 95\% Confidence Interval & Lower Bound & 3.2821 & \\
\hline & & for Mean & Upper Bound & 3.6948 & \\
\hline & & $5 \%$ Trimmed Mean & & 3.5278 & \\
\hline & & Median & & 3.5000 & \\
\hline & & Variance & & .261 & \\
\hline & & Std. Deviation & & .51094 & \\
\hline & & Minimum & & 2.20 & \\
\hline & & Maximum & & 4.00 & \\
\hline & & Range & & 1.80 & \\
\hline & & Interquartile Range & & .65 & \\
\hline & & Skewness & & -.935 & .456 \\
\hline & & Kurtosis & & .206 & .887 \\
\hline
\end{tabular}

Hal ini menunjukkan bahwa rata-rata kemampuan Kelas B lebih baik daripada Kelas A, tetapi perbedaannya tidak signifikan. Jika dilihat dari standar deviasinya, Kelas A dan B yaitu 0.56 dan 0,51. Standar deviasi Kelas A lebih besar sedikit dari Kelas B, artinya nilai-nilai individu di kelas A dan B jaraknya hampir sama dari nilai rata-rata masing-masing kelas.

Data N-gain ditampilkan pada tabel 4 di bawah ini. N-Gain minimum kelas A dan B adalah 0,10 dan 0,18. N-Gan maksimum kedua kelas sama yaitu 1,0. Rata-rata N-Gain kedua kelas yaitu 0,68 dan 0,78. Hal ini menunjukkan bahwa rata-rata peningkatan Kelas B lebih baik daripada Kelas A, tetapi perbedaannya belum tentu signifikan, harus diuji terdahulu. Jika dilihat dari standar deviasinya, Kelas A dan B yaitu 0.21 dan 0,22. Standar deviasi Kelas B lebih besar sedikit dari Kelas A, artinya N-Gain individu di kelas A dan B jaraknya hampir sama dari nilai rata-rata $\mathrm{N}$-Gain masing-masing kelas. 


\section{Tabel 4. Statistika Deskriptif N-Gain}

\begin{tabular}{|c|c|c|c|c|c|}
\hline \multicolumn{6}{|c|}{ Descriptives } \\
\hline & Kelas & & & Statistic & Std. Error \\
\hline \multirow{26}{*}{ N-Gain } & \multirow{13}{*}{ Kelas A } & Mean & & .6805 & .03575 \\
\hline & & $95 \%$ Confidence Interval for & Lower Bound & 6079 & \\
\hline & & Mean & Upper Bound & .7532 & \\
\hline & & 5\% Trimmed Mean & & .6915 & \\
\hline & & Median & & .6800 & \\
\hline & & Variance & & .045 & \\
\hline & & Std. Deviation & & .21152 & \\
\hline & & Minimum & & .10 & \\
\hline & & Maximum & & 1.00 & \\
\hline & & Range & & .90 & \\
\hline & & Interquartile Range & & .25 & \\
\hline & & Skewness & & -.874 & .398 \\
\hline & & Kurtosis & & .685 & .778 \\
\hline & \multirow{13}{*}{ Kelas B } & Mean & & .7754 & .04330 \\
\hline & & $95 \%$ Confidence Interval for & Lower Bound & .6862 & \\
\hline & & Mean & Upper Bound & .8645 & \\
\hline & & 5\% Trimmed Mean & & .7931 & \\
\hline & & Median & & .8139 & \\
\hline & & Variance & & .049 & \\
\hline & & Std. Deviation & & .22078 & \\
\hline & & Minimum & & .18 & \\
\hline & & Maximum & & 1.00 & \\
\hline & & Range & & .82 & \\
\hline & & Interquartile Range & & .30 & \\
\hline & & Skewness & & -.953 & .456 \\
\hline & & Kurtosis & & .518 & .887 \\
\hline
\end{tabular}

\section{Analisis Data Peningkatan}

Pada Tabel 5, kita dapat mendeskripsikan bahwa banyaknya sampel mahasiswa Kelas A yang mengontrak Mata Kuliah Aljabar Matriks adalah 35 orang. Kemudian rata-rata peningkatannya yaitu 0.68 , dan berada pada kategori sedang.

Tabel 5. Uji-t Satu Sampel Mahasiswa Kelas A

One-Sample Statistics

\begin{tabular}{|c|c|c|c|c|}
\hline & $\mathrm{N}$ & Mean & Std. Deviation & Std. Error Mean \\
\hline & 35 & 6805 & .21152 & .03575 \\
\hline
\end{tabular}

Untuk mengetahui kemampuan kreatif mahasiswa Kelas A meningkat secara signifikan atau tidak pada kategori nilai 0.68, maka diperlukan analisis statistika inferensial yaitu uji-t satu sampel (one sample test). Berikut ini adalah analisis peningkatan penalaran dengan SPSS 23.00. 
Tabel 6. Analisis Peningkatan Kemampuan Kreatif Kelas A

\begin{tabular}{|c|c|c|c|c|c|c|}
\hline \multicolumn{7}{|c|}{ One-Sample Test } \\
\hline & \multicolumn{6}{|c|}{ Test Value $=0.68$} \\
\hline & $\mathrm{T}$ & df & Sig. (2-tailed) & $\begin{array}{c}\text { Mean } \\
\text { Difference }\end{array}$ & $\begin{array}{l}95 \% \text { Confidenc } \\
\text { Diffe }\end{array}$ & erval of the \\
\hline & & & & & Lower & Upper \\
\hline N-Gain & 295 & 34 & .770 & . 01053 & -.0621 & .0832 \\
\hline
\end{tabular}

Pada Tabel 6 , dengan test value $=0.68$ yang diambil dari nilai rata-rata, diperoleh kesimpulan bahwa peningkatan kemampuan kreatif tersebut tidak meningkat secara signifikan pada nilai tersebut, karena nilai Sig. $(2$-tailed $=0,770)>0.05$, yaitu H0 diterima.

Pada Tabel 7, kita dapat mendeskripsikan bahwa banyaknya sampel mahasiswa Kelas B yang mengontrak Mata Kuliah Aljabar Matriks adalah 26 orang. Kemudian rata-rata peningkatannya yaitu 0.78 , dan berada pada kategori tinggi.

Tabel 7. Uji-t Satu Sampel Mahasiswa Kelas B

\begin{tabular}{lcccc}
\multicolumn{5}{c}{ One-Sample Statistics } \\
& $\mathrm{N}$ & Mean & Std. Deviation & $\begin{array}{c}\text { Std. Error } \\
\text { Mean }\end{array}$ \\
\hline N-Gain & 26 & .7754 & .22078 & .04330 \\
\hline
\end{tabular}

Untuk mengetahui kemampuan kreatif mahasiswa Kelas B meningkat secara signifikan atau tidak pada kategori nilai 0.68, maka diperlukan analisis statistika inferensial yaitu uji-t satu sampel (one sample test). Berikut ini adalah analisis peningkatan kemampuan kreatif dengan SPSS 23.00.

Tabel 8. Analisis Peningkatan Kemampuan Kreatif Kelas B

\begin{tabular}{ccccccc}
\hline \multicolumn{7}{c}{ One-Sample Test } \\
\cline { 2 - 7 } & & df & Sig. (2-tailed) & Mean & Test Value $=0.78$ \\
& & & & Difference & \multicolumn{2}{c}{$\begin{array}{c}\text { Confidence Interval of the } \\
\text { Difference }\end{array}$} \\
\cline { 2 - 7 } N-Gain & -.107 & 25 & .916 & -.00463 & -.0938 & .0845 \\
\hline
\end{tabular}

Pada Tabel 6, dengan test value $=0.78$ yang diambil dari nilai rata-rata, diperoleh kesimpulan bahwa peningkatan kemampuan kreatif tersebut meningkat secara signifikan pada nilai tersebut, karena nilai Sig. (2-tailed $=0,770)>0.05$, yaitu $\mathrm{H}_{0}$ diterima.

Untuk melihat perbedaan peningkatan antara Kelas A dan B, maka dilakukan analisis perbandingan. Oleh karena itu, diperlukan uji normalitas untuk mengetahui apakah statistika parametris atau non parametris yang digunakan. 
Tabel 9. Uji Normalitas Data Peningkatan Kelas A dan B

Tests of Normality

\begin{tabular}{llrrrrrr}
\hline & \multirow{2}{*}{ Kelas } & \multicolumn{3}{c}{ Kolmogorov-Smirnov $^{\mathrm{a}}$} & \multicolumn{3}{c}{ Shapiro-Wilk } \\
\cline { 3 - 8 } & & Statistic & df & \multicolumn{1}{c}{ Sig. } & Statistic & df & \multicolumn{1}{l}{ Sig. } \\
\hline \multirow{2}{*}{ N-Gain } & Kelas A & .152 & 35 & .040 & .939 & 35 & .053 \\
& Kelas B & .170 & 26 & .051 & .887 & 26 & .008 \\
\hline
\end{tabular}

a. Lilliefors Significance Correction

Pada Tabel 9, nilai signifikan kelas A adalah 0.53 dan Kelas B adalah 0,08, keduanya < 0.05 , sehingga data kedua kelas tidak normal. Oleh karena itu, analisis perbandingan yang digunakan adalah statistika non parametris, yaitu Uji Mann Whitney U.

Tabel 10. Analisis Perbandingan Peningkatan

\begin{tabular}{lr}
\multicolumn{2}{c}{ Test Statistics $^{\mathbf{a}}$} \\
\hline \multicolumn{2}{c}{ N-Gain } \\
\hline Mann-Whitney U & 325.000 \\
Wilcoxon W & 955.000 \\
Z & -1.899 \\
Asymp. Sig. (2-tailed) & .058 \\
a. Grouping Variable: Kelas & \\
\hline
\end{tabular}

Pada Tabel 10, nilai signifikansinya $0,58>0,05$ sehingga $\mathrm{H} 0$ diterima, yaitu tidak terdapat perbedaan peningkatan yang signifikan kemampuan kreatif antara kelas A dan B.

\section{KESIMPULAN}

Pembelajaran STEM secara deskriptif mampu peningkatan kemampuan kreatif dengan kategori sedang di Kelas A dan Kategori tinggi di Kelas B, meskipun tidak meningkat secara signifikan. Tidak terdapat perbedaan peningkatan yang signifikan kemampuan kreatif antara kelas A dan B, karena mempunyai nilai rata-rata peningkatan yang hampir sama.

\section{REFERENSI}

Bybee, W. R. (2013). The Case for STEM Education Challenges and Oppartunities. Amerika: NSTA.

Darmawan, J. (2018). Menjadi Guru pada Era Pendidikan 4.0. Tribunnews. [Online]. Tersedia di: https://aceh.tribunnews.com/2018/11/27/menjadi-guru-era-pendidikan-4.0.

Darta and Saputra, J. (2018). Indicators that Influence Prospective Mathematics Teachers Representational and Reasoning Abilities. Journal of Physics: Conference Series 948 (1), 012053. DOI: $10.1088 / 1742-6596 / 948 / 1 / 012053$ 
Mangunhardjana. A. M, (1986). Pembinaan: Arti dan Metodenya, Kanisius, Yogyakarta.

Marwiyah. A. dan Umar, K. M. (2018). Perencanaan Pembelajaran Kontemporer Berbasis Penerapan Kurikulum 2013. CV Budi Utama: Yogyakarta.

Maulana, G., G., dan Saputra, J. (2018). Penggunaan Metode Pembelajaran Outdoor Learning untuk Meningkatkan Hasil Belajar Siswa pada Subkonsep Vertebrata. BIOSFER: Jurnal Biologi dan Pendidikan Biologi, 3 (1), hlm. 30-33. DOI: http://dx.doi.org/10.23969/biosfer.v3i2.1263

Munandar, U. (1990) Mengembangkan Bakat dan Kreativitas Anak Sekolah. Jakarta: PT Gramedia.

Munandar, U. (1995) Pengembangan Kreativitas Anak Berbakat. Jakarta: P.T Rineka Cipta.

Munandar, U. (2004). “Pengembangan Emosi dan Kreativitas”. Jakarta; Rineka Cipta.M.M Sutopo, Tjetjep.2005.” Pengembangan Kreativitas Anak”. Bandung: Depdiknas.

Munandar, U. (2009) Pengembangan Kreatifitas Anak Berbakat. Jakarta: Rineka Cipta

Musbikin, I. (2006). Mendidik Anak Kreatif Ala Einstein. Mitra Pustaka James

National Research Council (NRC). (2014). Nutrient Requirement of Poultry, 9th Revised Edition. National Academy Press, Washington DC.

Nurhayati, Nunung dan Wijayanti, R. (2017). Biologi untuk SMA/MA kelas XI kelompok peminatan matematika dan ilmu-ilmu alam kurikulum 2013. Bandung: Yrama Widya

Pertiwi, R. S., Abdurrahman, R., U. (2017) berjudul Efektivitas LKS Stem Untuk Melatih Keterampilan Berpikir Kreatif Siswa Pembelajaran fisika vol 5, NO 2 (2017), http://jurnal.fkip.unila.ac.id/index.php/JPF/article/view/12095/8670

Rachmawati, Y. dan Kurniati, E. 2010. Strategi Pengembangan Kreativitas Pada Anak Usia Taman Kanak-kanak. Jakarta: Kencana Prenada Media Group

Reni, A. dan Hawadi. 2001. Psikologi Perkembangan Anak. Jakarta: Grasindo

Saputra, J. (2015). Program Maple Untuk Meningkatkan Kemampuan Komunikasi Matematis Mahasiswa Calon Guru. SYMMETRY Jurnal Pendidikan Matematika, 4 (2), hlm. 597-605 Saputra, J. (2017a). The Application of The Maple Program to Self-Regulated Learning on The Mathematics' Prospective Teachers Students. International Conference: Character Building Through Pricesly International Education. Tersedia di http://proceedings.conference.unpas.ac.id/index.php/ice/article/view/256/223 
Saputra, J. (2017b). Penggunaan Model Problem Based Learning Berbantuan E-Learning Terhadap Kemandirian Belajar Mahasiswa pada Dimensi Tiga. KALAMATIKA Jurnal Pendidikan Matematika, 2 (2), 117-130. DOI: http://dx.doi.org/10.22236/ KALAMATIKA.vol2no2.2017pp117-130

Sternberg, R.J. (1988). The psychology of love. USA: Yale University

Thibaut, L., Knipprath, H., Dehaene, W., Depaepe, F. (2018), Berjudul The Influence of Teachers' Attitudes and School Context on Instructional Practices in Integrated STEM Education journal Teaching and Teacher Education 71 (2018) https://doi.org/10.1016/j.tate.2017.12.014

Torrance, E. P. (1988). The nature of creativity as manifest in its test-. New York: Cambridge University Press.

Yaniawati, R., P., Kartasasmita, B. G. and Saputra, J. (2019). E-learning assisted problem-based learning for self-regulated learning and mathematical problem solving. Journal of Physics: Conference Series 1280 (4), 042023. DOI: 10.1088/1742-6596/1280/4/042023 